\title{
RELATIVE IMPORTANCE OF FIRE RESISTANCE PERFORMANCE OF PARTITION WALLS
}

\author{
Ming-Chin Ho \\ Architecture and Building Research Institute, Ministry of the Interior, Taipei County, Taiwan, R.O. \\ Ming-Ju Tsai \\ Architecture and Building Research Institute, Ministry of the Interior, Taipei County, Taiwan, R.O., ming-ju@abri.gov.tw
}

Follow this and additional works at: https://jmstt.ntou.edu.tw/journal

Part of the Civil and Environmental Engineering Commons

\section{Recommended Citation}

Ho, Ming-Chin and Tsai, Ming-Ju (2010) "RELATIVE IMPORTANCE OF FIRE RESISTANCE PERFORMANCE OF PARTITION WALLS," Journal of Marine Science and Technology. Vol. 18: Iss. 3, Article 14.

DOI: $10.51400 / 2709-6998.1890$

Available at: https://jmstt.ntou.edu.tw/journal/vol18/iss3/14

This Research Article is brought to you for free and open access by Journal of Marine Science and Technology. It has been accepted for inclusion in Journal of Marine Science and Technology by an authorized editor of Journal of Marine Science and Technology. 


\title{
RELATIVE IMPORTANCE OF FIRE RESISTANCE PERFORMANCE OF PARTITION WALLS
}

\author{
Ming-Chin $\mathrm{Ho}^{*}$ and Ming-Ju Tsai*
}

Key words: partition wall, Taguchi experimental design analysis method, fire resistance performance.

\begin{abstract}
The fire performance of partitions is influenced by the thickness, type, combustibility level of panel material, type of filling material and frame. However, realizing the importance of these parameters is not of enough help for interior designers. They need more quantitative information of the relative importance of the parameters so that they can select materials with cost consideration. Experiments were thus designed and analyzed by the Taguchi experimental design analysis method for it is good to determine the effect of each parameter especially as the number of parameters is large. Our data and analysis show that the thickness of panel layer is the most important parameter, and the type of the panel material is the second one. The combustibility of panel material, type of filling material and frame do not have significant effect.
\end{abstract}

\section{INTRODUCTION}

In a building, walls are commonly seen to separate the spaces for different uses. While a fire starts in an enclosure formed by walls, the fire may spread to the walls and even propagates on them as the materials are combustible. The resultant wall fires are regarded to be a trigger to flashover and have been studied for decades [2, 7-10]. In addition, walls have another function. Once the fires in the enclosures grow up, the walls should play a role of barriers to delay or prevent combustion products moving from one space to an adjacent space [1].

Many types of walls can be chosen for different advantages, and light partition walls are very popular in Taiwan especially when more and more high-rise buildings have been and are being constructed. Partition walls, which are easily assembled by panels, frames and filling materials often by sandwich dry construction method, are not heavy, and the cost is low. Manzello et al. [6] have studied the real fire performance of

Paper submitted 11/21/08; revised 07/09/09; accepted 07/16/09. Author for correspondence: Ming-Ju Tsai (e-mail: ming-ju@abri.gov.tw).

*Architecture and Building Research Institute, Ministry of the Interior, Taipei County, Taiwan, R.O.C partition assemblies. They provided information on the phenomenology of partition response and failure by the data of heat flux on the exposed face of the partitions and temperature rise on the unexposed face to determine the heat through the partitions. Besides, a study conducted in China [12] focused on the effect of thickness of the panels and demonstrated this parameter is important. The parameters which influence the fire resistant performance of partition walls include the type of panel material and its combustibility, type of filling material and frame in addition to the panel thickness [3-5, 11, 13]. However, even with the knowledge of realizing the important parameters, it is still not of enough help for the interior finishing industry to select materials for fire safety. The designers need further quantitative information, i.e., the relative importance of the parameters, so they can choose materials with cost consideration. This study consequently devotes to determining the relative importance of the parameters by means of the Taguchi experimental design analysis method.

\section{EXPERIMENTAL DESIGN}

Experiments are designed to study the fire resistance performance of partition walls and the data will be analyzed by the Taguchi experimental design analysis method to determine the relative importance of the parameters.

\section{Principle of the Taguchi Experimental Design Analysis}

Right after the World War II, ELC (Electrical Communication Lab., Japan) initiated a program for Japanese communication system improvement. Dr. Taguchi was in charge of productivity reinforcement in ECL and developed an experimental design method to analyze the cost and quality. The details of the Taguchi experimental design analysis method can be seen in [5]. Briefly described, Taguchi applied a totally different experimental design concept to determine the influence of each parameter. In traditional experimental design methods, the parameters are changed one by one and the effect of one parameter is compared under fixed conditions. For example, one parameter A has two levels, A1 and A2. A1 and A2 will be experimentally studied with other parameters B, C, $\mathrm{D}$, etc. fixed. However, if the result is influenced by many parameters, the times of experiments will be terribly large. Meanwhile, the Taguchi experimental design analysis method 
Table 1. Parameters and levels.

\begin{tabular}{|c|c|}
\hline Parameters & Level \\
\hline \multirow{2}{*}{ A. Panel Thickness } & $1.12 \mathrm{~mm}$ \\
\hline & $2.12 \mathrm{~mm}+12 \mathrm{~mm}$ \\
\hline \multirow{2}{*}{$\begin{array}{l}\text { B. Incombustibility Level of } \\
\text { Panel }\end{array}$} & 1. First class \\
\hline & 2. Second class \\
\hline \multirow{2}{*}{ C. Panel Material Type } & 1. Gypsum board \\
\hline & 2. Fiber-cement board \\
\hline \multirow{2}{*}{ D. Filling Material } & 1. Rock wool \\
\hline & 2. Glass fiber wool \\
\hline \multirow[b]{2}{*}{ E. Frame } & 1. Wood frame \\
\hline & $\begin{array}{l}\text { 2. Galvanized Lightweight Steel } \\
\text { Frame }\end{array}$ \\
\hline
\end{tabular}

Table 2. Density and thickness of panel and filling materials.

\begin{tabular}{|c|c|c|c|}
\hline Material & $\begin{array}{c}\text { Thickness } \\
(\mathrm{mm})\end{array}$ & $\begin{array}{c}\text { Density } \\
\left(\mathrm{kg} / \mathrm{m}^{3}\right)\end{array}$ & $\begin{array}{c}\text { Incombustibility } \\
\text { class }\end{array}$ \\
\hline \multirow{2}{*}{ gypsum board } & 12 & 780.4 & first \\
\cline { 2 - 4 } & 12 & 734.7 & second \\
\hline $\begin{array}{c}\text { fiber-cement } \\
\text { board }\end{array}$ & 12 & 1355.8 & first \\
\cline { 2 - 4 } & 12 & 1468.7 & second \\
\hline glass wool & 50 & 24 & \\
\hline rock wool & 50 & 60 & \\
\hline
\end{tabular}

analyzes the parameters in another way, expressing each parameter a certain function. These functions of parameters can fully show the relationship between the cost, quality and a target value. The quality of a product is then determined by estimating the MSD (Mean Square Deviation) value of the functions. The time and financial cost will be low using the analysis method.

\section{Experimental Parameter Design}

Table 1 lists the parameters studied and its levels. The selected materials fully reflect the commonly used materials and construction method of the fireproofing partition walls in Taiwan. The selected experimental frames include lightweight steel frame and wood frame while two kinds of gypsum board and two kinds of fiber-cement board classified as the first and second class fire retardant materials according to Taiwanese National Standard CNS 6532 were used for panel materials. Besides, rock wool and glass wool were used as filling material. The density and thickness of these materials are listed in Table 2.

Table 3 lists the materials of the specimens and Figs. 1 to 3 demonstrate the construction method. The experimental design is showed in Table 4, an L8 orthogonal array. Experiments were conducted using a $90 \times 90 \mathrm{~cm}$ furnace according to Taiwanese national standard CNS 12514, equivalent to ISO 834. Table 5 demonstrates the history of temperature rise and the test time is 120 minutes. Figure 4 shows the temperature
Table 3. Materials of test specimens.

\begin{tabular}{|c|c|c|c|c|c|}
\hline No. & $\begin{array}{c}\text { Panel } \\
\text { Thickness }\end{array}$ & $\begin{array}{c}\text { Incombustibility } \\
\text { Level }\end{array}$ & $\begin{array}{c}\text { Panel Material } \\
\text { Type }\end{array}$ & Filler & Frame \\
\hline 1 & $12 \mathrm{~mm}$ & First Level & $\begin{array}{c}\text { Gypsum } \\
\text { Plasterboard }\end{array}$ & $\begin{array}{c}\text { Rock } \\
\text { Wool }\end{array}$ & Wood Frame \\
\hline 2 & $12 \mathrm{~mm}$ & First Level & $\begin{array}{c}\text { Fiber-Cement } \\
\text { Board }\end{array}$ & $\begin{array}{c}\text { Glass } \\
\text { Wool }\end{array}$ & $\begin{array}{l}\text { Lightweight } \\
\text { Steel Frame }\end{array}$ \\
\hline 3 & $12 \mathrm{~mm}$ & Second Level & $\begin{array}{c}\text { Gypsum } \\
\text { Plasterboard }\end{array}$ & $\begin{array}{c}\text { Glass } \\
\text { Wool }\end{array}$ & $\begin{array}{l}\text { Lightweight } \\
\text { Steel Frame }\end{array}$ \\
\hline 4 & $12 \mathrm{~mm}$ & Second Level & $\begin{array}{c}\text { Fiber-Cement } \\
\text { Board }\end{array}$ & $\begin{array}{c}\text { Rock } \\
\text { Wool }\end{array}$ & Wood Frame \\
\hline 5 & $24 \mathrm{~mm}$ & First Level & $\begin{array}{c}\text { Gypsum } \\
\text { Plasterboard }\end{array}$ & $\begin{array}{c}\text { Rock } \\
\text { Wool }\end{array}$ & $\begin{array}{c}\text { Lightweight } \\
\text { Steel Frame }\end{array}$ \\
\hline 6 & $24 \mathrm{~mm}$ & First Level & $\begin{array}{c}\text { Fiber-Cement } \\
\text { Board }\end{array}$ & $\begin{array}{c}\text { Glass } \\
\text { Wool }\end{array}$ & Wood Frame \\
\hline 7 & $24 \mathrm{~mm}$ & Second Level & $\begin{array}{c}\text { Gypsum } \\
\text { Plasterboard }\end{array}$ & $\begin{array}{c}\text { Glass } \\
\text { Wool }\end{array}$ & Wood Frame \\
\hline 8 & $24 \mathrm{~mm}$ & Second Level & $\begin{array}{c}\text { Fiber-Cement } \\
\text { Board }\end{array}$ & $\begin{array}{c}\text { Rock } \\
\text { Wool }\end{array}$ & $\begin{array}{l}\text { Lightweight } \\
\text { Steel Frame }\end{array}$ \\
\hline
\end{tabular}

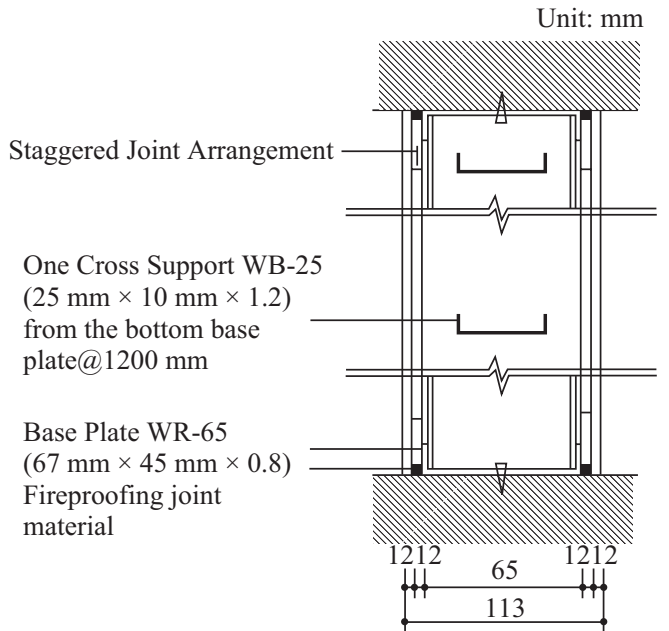

Fig. 1. Construction method of specimen (vertical section).

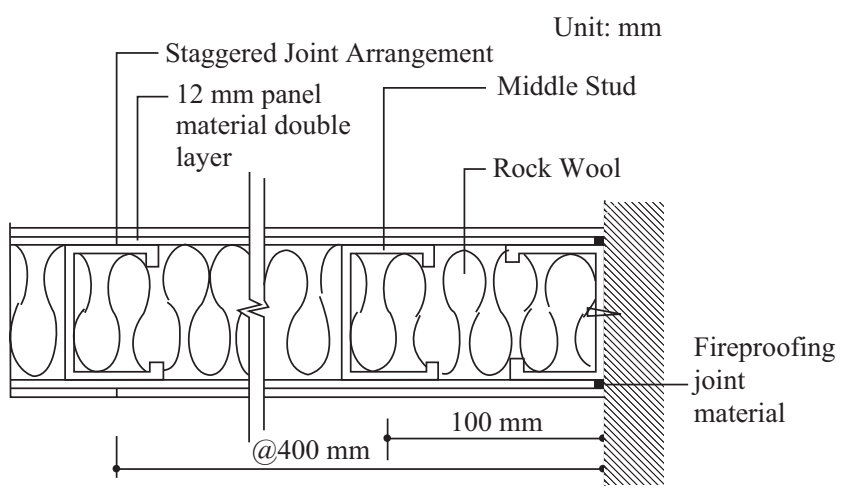

Fig. 2. Construction method of specimen (horizontal section).

measuring position on unexposed surface. The fire performance of the specimens will be determined by the effect on heat 


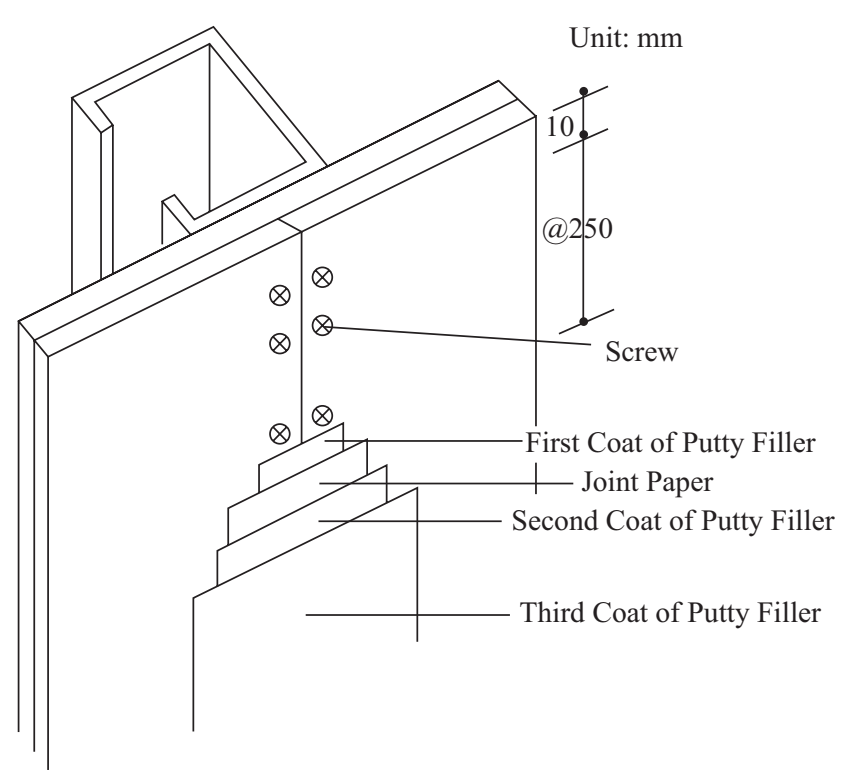

Fig. 3. Construction method of specimen (joint).

Table 4. Orthogonal arrays table.

\begin{tabular}{|c|c|c|c|c|c|c|c|}
\hline $\begin{array}{c}\text { Factor } \\
\text { Level }\end{array}$ & $\mathrm{A}$ & $\mathrm{B}$ & $\mathrm{A} \times \mathrm{B}$ & $\mathrm{C}$ & $\mathrm{A} \times \mathrm{C}$ & $\mathrm{D}$ & $\mathrm{E}$ \\
\hline 1 & 1 & 1 & 1 & 1 & 1 & 1 & 1 \\
\hline 2 & 1 & 1 & 1 & 2 & 2 & 2 & 2 \\
\hline 3 & 1 & 2 & 2 & 1 & 1 & 2 & 2 \\
\hline 4 & 1 & 2 & 2 & 2 & 2 & 1 & 1 \\
\hline 5 & 2 & 1 & 2 & 1 & 2 & 1 & 2 \\
\hline 6 & 2 & 1 & 2 & 2 & 1 & 2 & 1 \\
\hline 7 & 2 & 2 & 1 & 1 & 2 & 2 & 1 \\
\hline 8 & 2 & 2 & 1 & 2 & 1 & 1 & 2 \\
\hline
\end{tabular}

Note: $\mathrm{A} \times \mathrm{B}$ and $\mathrm{A} \times \mathrm{C}$ represent the interaction between $\mathrm{A}$ and $\mathrm{B}$, and $\mathrm{A}$ and $\mathrm{C}$.

Table 5. Time history of temperature rise of CNS 12514.

\begin{tabular}{|l|r|r|r|r|r|r|}
\hline \multicolumn{1}{|c|}{ Time $(\mathrm{min})$} & \multicolumn{1}{c|}{5} & \multicolumn{1}{c|}{10} & \multicolumn{1}{c|}{15} & \multicolumn{1}{c|}{20} & \multicolumn{1}{c|}{25} & \multicolumn{1}{c|}{30} \\
\hline Temperature $\left({ }^{\circ} \mathrm{C}\right)$ & 576 & 678 & 739 & 781 & 815 & 842 \\
\hline Time (min) & 35 & 40 & 45 & 50 & 55 & 60 \\
\hline Temperature $\left({ }^{\circ} \mathrm{C}\right)$ & 865 & 885 & 902 & 918 & 932 & 945 \\
\hline Time (min) & 65 & 70 & 75 & 80 & 85 & 90 \\
\hline Temperature $\left({ }^{\circ} \mathrm{C}\right)$ & 957 & 968 & 979 & 988 & 997 & 1006 \\
\hline Time (min) & 95 & 100 & 110 & 120 & & \\
\hline Temperature $\left({ }^{\circ} \mathrm{C}\right)$ & 1014 & 1022 & 1036 & 1049 & & \\
\hline
\end{tabular}

insulation and the integrity of the partition as follows. First, damage like deformation, destruction, falling off should not occur. Second, no crack which flame can pass through is allowed during the heating. Finally, temperature of the unexposed surface does not surpass $210^{\circ} \mathrm{C}$. The fire resistant

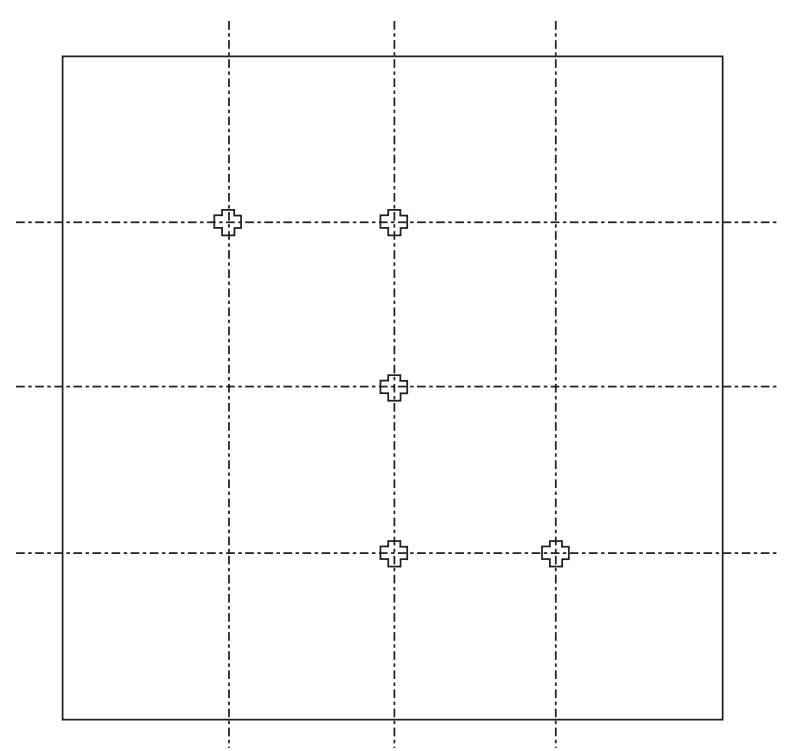

Fig. 4. Measuring points of temperature on the unexposed surfaces.

Table 6. Fire resistance effectiveness (min) of each specimen.

\begin{tabular}{|c|r|r|r|c|}
\hline No. & \multicolumn{3}{|c|}{ FRE (min) } & Total \\
\hline 1 & 53 & 60 & 57 & 170 \\
\hline 2 & 52 & 58 & 62 & 172 \\
\hline 3 & 40 & 35 & 49 & 124 \\
\hline 4 & 50 & 53 & 57 & 160 \\
\hline 5 & 92 & 99 & 90 & 281 \\
\hline 6 & 120 & 120 & 120 & 360 \\
\hline 7 & 71 & 73 & 72 & 216 \\
\hline 8 & 120 & 120 & 120 & 360 \\
\hline
\end{tabular}

effectiveness (FRE) is then determined by the time one of the three criteria fails.

\section{EXPERIMENTAL RESULT AND DISCUSSION}

\section{Taguchi Experiment Result Analysis}

Table 6 lists the fire resistance effectiveness (FRE) of each specimen. The values of FRE are used to calculate the response value and to determine the main effect of each parameter. In addition, the interaction with other parameters, the response table and response graph will be conducted according to the FRE values.

\section{1) Response Value of Each Parameter}

The response value of each parameter is defined to be the average of corresponding FRE values. For instance, for level 1 of parameter A (A1), its response value is the average of corresponding FRE values (Table 6) divided by the times of appearance of the A1 from interaction table (Table 4). The 


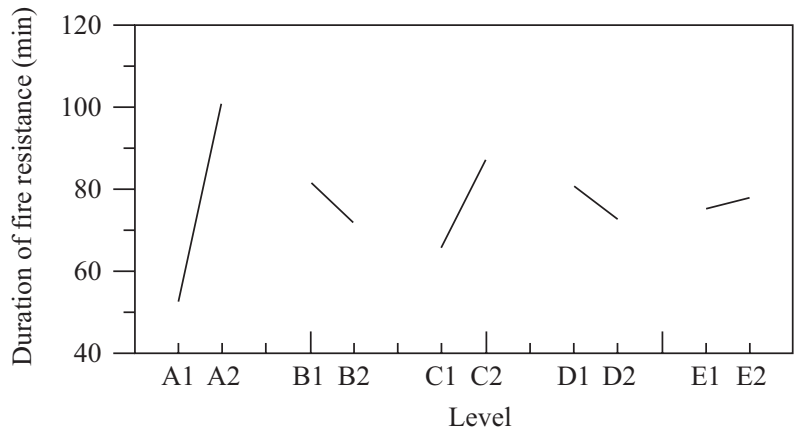

Fig. 5. The effect of parameter.

calculation of other response values is as follows.

Number of FRE values $N=24$

Total value of FRE

$$
\begin{aligned}
T=\sum_{i=1}^{n} Y_{i} & =(53+60+57+52+\ldots \ldots+120+120+120) \\
& =1843
\end{aligned}
$$

Averaged FRE $\bar{T}=1843 / 24=76.79$

Total FRE value of A1 $=170+172+124+160=626$

Averaged FRE Value of A $\overline{A_{1}}=626 / 12=52.2$

Averaged FRE Value of $\overline{A_{2}}=(281+360+216+360) / 12$

$$
=101.4
$$

The average values of $\mathrm{B}, \mathrm{C}, \mathrm{D}, \mathrm{E}, \mathrm{A} \times \mathrm{B}, \mathrm{A} \times \mathrm{C}$ can be obtained by the same way. The averaged FRE values of B1, B2, $\mathrm{C} 1, \mathrm{C} 2, \mathrm{D} 1, \mathrm{D} 2, \mathrm{E} 1, \mathrm{E} 2,(\mathrm{~A} \times \mathrm{B}) 1,(\mathrm{~A} \times \mathrm{B}) 2,(\mathrm{~A} \times \mathrm{C}) 1$ and $(\mathrm{A} \times \mathrm{C}) 2$ are 81.9, 71.7, 65.9, 87.7, 80.9, 72.7, 75.5, 78.3, 76.5, $77.1,84.5$ and 69.1 , respectively.

\section{2) Main Effects of Each Parameter and Interaction}

The main effect of each parameter is determined by the values of level 1 and 2 of each parameter. The larger the difference, the stronger the effect of this parameter. The relative importance of each parameter on the fire performance is then determined. The calculations are shown as follows:

Main Effect of A: $\mid$ A1 - A2 $|=| 52.5-101.4 \mid=48.9$

Main Effect of B: $|\mathrm{B} 1-\mathrm{B} 2|=|81.9-71.7|=10.2$

Main Effect of C: $|\mathrm{C} 1-\mathrm{C} 2|=|65.9-87.7|=21.8$

Main Effect of D: $\mid$ D1 - D2 $|=| 80.9-72.7 \mid=8.2$

Main Effect of E: $|\mathrm{E} 1-\mathrm{E} 2|=|75.5-78.3|=2.8$

Main Effect of $\mathrm{A} \times \mathrm{B}:|(\mathrm{A} \times \mathrm{B}) 1-(\mathrm{A} \times \mathrm{B}) 2|=|76.5-77.1|$ $=0.6$

Main Effect of $\mathrm{A} \times \mathrm{C}:|(\mathrm{A} \times \mathrm{C}) 1-(\mathrm{A} \times \mathrm{C}) 2|=|84.5-69.1|$

$$
=15.4
$$

\section{Response Graph}

Figure 5 demonstrates the response graphs of each parameter. The slope expresses the effect of each parameter.

\section{Discussion}

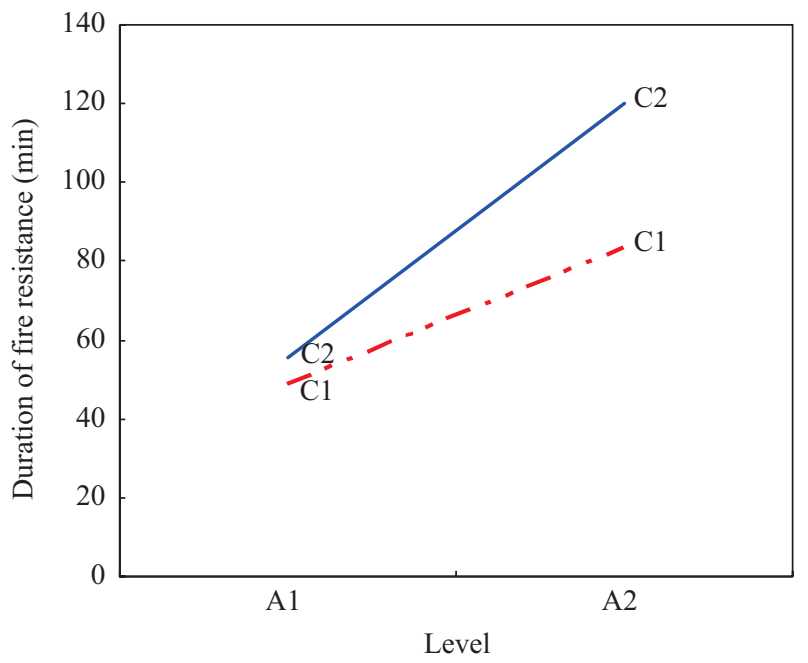

Fig. 6. The interaction of panel thickness (parameter A) and panel material type (parameter C).

From Fig. 5, it can be seen that the panel thickness (parameter A) plays the most important role on the fire resistance performance of fire walls in this study. For specimens with thinner panel, it is easy for the panels to fall off due to the material deterioration and thermal deformation caused by flame and heat. The fire performance of the whole walls consequently would reduce rapidly if the panel does not have the efficacy of integrity. This is consistent with the observation of Wang et al. [8]. Furthermore, the second important parameter is the type of panel material (parameter C). In this study, fiber-cement board performed better than gypsum plasterboard. The gypsum plasterboard failed due to dehydration and powderizing after being heated. The Incombustibility level of panel material (parameter B), type of filling material (parameter D) and frame (parameter E) do not have significant influence on the fire performance of partitions.

Moreover, the response graph (Fig. 6) is constructed according to Taguchi method. Grouping the experimental results by parameter A first, we have two sets of data from Table 4, i.e., $\mathrm{A} 1(1,2,3,4)$ and $\mathrm{A} 2(5,6,7,8)$. By averaging the duration of fire resistance for each data set, we have the effect of parameter $\mathrm{C}$ from Table 6, i.e., $\mathrm{A} 1 \mathrm{C} 1(1,3), \mathrm{A} 1 \mathrm{C} 2(2,4)$, A2C1 $(5,7)$, A2C2 $(6,8)$.

Since it is observed that $\mathrm{C} 1$ and $\mathrm{C} 2$ under $\mathrm{A} 1$ and $\mathrm{A} 2$ level would intersect, there is an interaction between parameter $\mathrm{C}$ and $\mathrm{A}$, which is in accordance with the analysis of the main effect of $\mathrm{A} \times \mathrm{C}(=15.4)$.

By similar technique, we can depict the response graph of parameter A and B as Fig. 7. It is clear that B1 and B2 are approximately parallel. Thus, there is no interaction as suggested by the calculation of main effect of $\mathrm{A} \times \mathrm{B}(=0.6)$.

\section{CONCLUSION AND SUGGESTION}

This study used Taguchi Experimental Design Analysis 


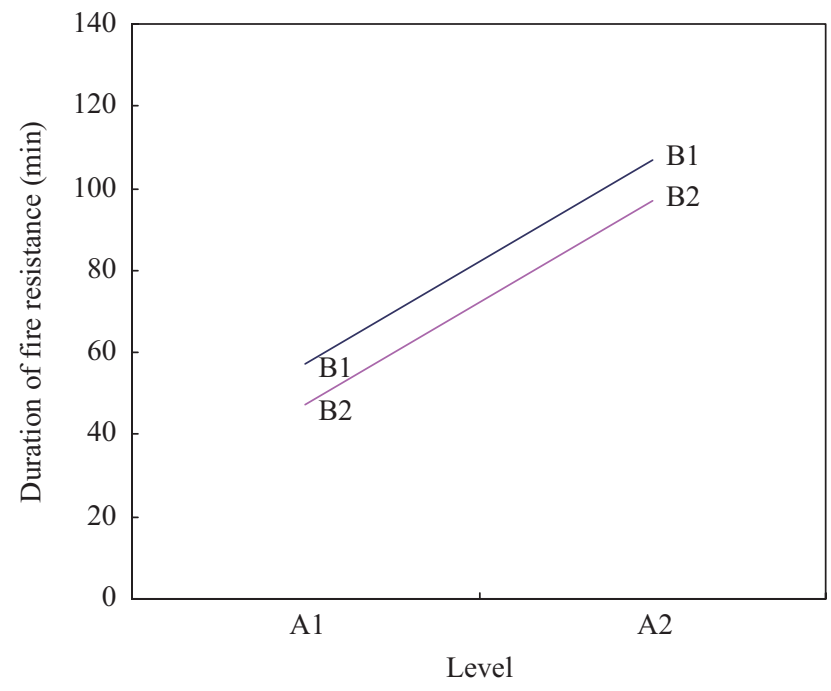

Fig. 7. No interaction of panel thickness (parameter A) and Incombustibility level of panel material (parameter $B$ ).

Method to verify the factors that influence the fire resistance performance of light partition walls. Parameters considered include the thickness, type, combustibility level of panel material, type of filling material and frame. Our data and analysis show that the thickness of panel layer is the most important parameter, and the type of the panel material is the second one. The combustibility of panel material, type of filling material and frame do not have significant effect.

\section{REFERENCES}

1. Fitzgerald, R., Building Fire Performance Analysis, Wiley publish, England (2004).

2. Graham, T. L., Makhviladze, G. M., and Roberts, J. P., "The effects of the thermal inertia of the walls upon flashover development," Fire Safety Journal, Vol. 32, Issue 1, pp. 35-60 (1999).

3. Ho, M. C. and Tsai, M. J., A Study on Building Fixed Partition Walls Fire Resistance Performance and Material Method, case study result report, Architecture and Building Research Institute, Ministry of the Interior, Taipei (1998).

4. Huang, R. Z. and Lin, Q. Y., A Study on Building Fireproof Door and Wall Design Requirement and Test Standards, case study result report, Architecture and Building Research Institute, Ministry of the Interior, Taipei (1991).

5. Lee, H. H., Taguchi Methods Principles and Practices of Quality Design, Gau Lih Book Co., Taipei (2003).

6. Manzello, S., Gann, R., Kukuck, S., Prasad, K., and Jones, W., "Real fire performance of partition assemblies," Fire and Materials, Vol. 29, No. 6, pp. 351-366 (2005)

7. Tsai, K. C., "Upward flame spread on a flat surface, in a corner and between two parallel surfaces," Journal of Chinese Society of Mechanical Engineering (2006).

8. Tsai, K. C., "Width effect on upward flame spread," Fire Safety Journal, Vol. 44, pp. 962-967 (2009).

9. Tsai, K. C. and Drysdale, D., "Using cone calorimeter data for the prediction of fire hazard," Fire Safety Journal, Vol. 37, pp. 697-706 (2002).

10. Tsai, K. C. and Drysdale, D., "Flame height in upward flame spread modeling," Fire and Materials, Vol. 26, pp. 279-287 (2002).

11. Tsai, M. J. and Ho, M. C., Building light partition walls fire resistance performance research meeting (1) a study on fire resistance performance influence factor, case study result report, Architecture and Building Research Institute, Ministry of the Interior, Taipei (1999).

12. Wang, Y. C., Qiu, H. F., He, Y. X., and Li, S. Q., The relationship between light incombustible wall thickness and refractory limit, Fire Prevention and Science, P13-15, China Fire, Tiangin (2000).

13. Zhang, W. Y., A Study on Light Partition Walls Fire Resistance Performance, Master's Degree Thesis, Department of Mechanical Engineering, National Chiao-Tung University, Hsinchu (1998). 